\title{
A Review on Management Strategies of the Terraced Agricultural Systems and Conservation Actions to Maintain Cultural Landscapes around the Mediterranean Area
}

\author{
Emanuela Cicinelli, Giulia Caneva *(D) and Valentina Savo \\ Department of Science, University Roma Tre, Viale Marconi 446, 00146 Rome, Italy; \\ emanuela.cicinelli@uniroma3.it (E.C.); valentina.savo@uniroma3.it (V.S.) \\ * Correspondence: giulia.caneva@uniroma3.it; Tel.:+39-0657336324
}

check for

updates

Citation: Cicinelli, E.; Caneva, G.; Savo, V. A Review on Management Strategies of the Terraced Agricultural Systems and Conservation Actions to Maintain Cultural Landscapes around the Mediterranean Area. Sustainability 2021, 13, 4475. https:// doi.org/10.3390/su13084475

Academic Editors: Iain J. Gordon and Alejandro Rescia

Received: 10 March 2021

Accepted: 13 April 2021

Published: 16 April 2021

Publisher's Note: MDPI stays neutral with regard to jurisdictional claims in published maps and institutional affiliations.

Copyright: (c) 2021 by the authors. Licensee MDPI, Basel, Switzerland. This article is an open access article distributed under the terms and conditions of the Creative Commons Attribution (CC BY) license (https:// creativecommons.org/licenses/by/ $4.0 /)$.

\begin{abstract}
Coupled human-environment systems and traditional agricultural landscapes can be a key element in the conservation of biodiversity, ecological functionality, and cultural heritage. Terraced landscapes are a relevant example of traditional landscapes within the Mediterranean area, but they are now threatened due to the abandonment of agricultural activities. In order to identify factors that can affect the conservation strategies needed to maintain terraced landscapes in the Mediterranean area, we performed a literature review on studies about terraces and their management, soil erosion and vegetation dynamics after abandonment, etc. We collated a total of 285 scientific papers reporting 293 case studies in 19 countries. The majority of these studies analyze dry stone terraces and their influence on soil erosion and water runoff, either in cultivated or abandoned terrace systems. Only a minority of papers suggest maintenance or conservation strategies or involve farmers, exploring their decision-making. The conservation of terraced landscapes is in the hands of local farmers, and thus they should be actively involved in decision-making to find the most suitable strategies for assuring the continuity in farming and preserve cultural landscapes in the Mediterranean area.
\end{abstract}

Keywords: social-ecological systems; management; coupled human-environment systems; cultural landscapes; conservation

\section{Introduction}

Most natural environments have now been replaced by coupled human-environment systems or social-ecological systems (SESs) [1]. If properly managed, SESs, such as many traditional farming systems, can retain high biodiversity and ecological functionality [2,3]. Cultivated terraces are considered one of the most typical and ancient traditional farming systems and are created to obtain arable land on steep slopes [4-7], contributing to reducing water runoff and soil loss [8,9] and simultaneously boosting biomass accumulation and soil water recharge [6,10-12]. These terraces are widespread across continents, from MesoSouth America to Eastern Africa, South-East Asia, and Mediterranean Europe [12,13].

Terraced landscapes have become a central topic in international policies such as the UNESCO World Heritage List or FAO's Globally Important Agricultural Heritage System (GIAHS). In Europe, terraced landscapes are protected through the Common Agricultural Policy (CAP) and other EU regulations, and farmers are eligible for funding to preserve them [14-17]. As a consequence of their relevance (hydrogeology, landscape, tourism, agriculture, etc.) $[14,18]$, there has been an increase in studies focused on terraced agriculture. However, terraced landscapes can change dramatically due to the abandonment of agricultural activities, which are often highly demanding in these areas [19-21].

The preservation of terraced landscapes, as for other SESs, depends on a variety of factors, including human action [1,22]. The goal of managing the resilience, and thus the stability, of an SES is to "prevent it from moving into undesirable configurations" [23]. A main undesirable configuration of a terraced system is its collapse (i.e., terrace failure and 
landslides). According to the literature, several factors may increase the risks of terrace failure, such as the inclination of the slope, the soil texture, the position of the terrace within a valley, the presence of shrubs on drystone walls, and above all the abandonment of terraces $[12,24]$. In this review we aim to present the management activities that farmers use to maintain the stability of terraces; we also identify the conservation strategies that could promote the preservation of this cultural landscape around the Mediterranean area.

\section{Materials and Methods}

Between May 2019 and January 2020, we performed a thorough literature review on terraced agriculture. We built on reviews on the topic $[12,24,25]$, and we conducted a search on the Internet for scientific articles using Google Scholar as a search engine and the following keywords "terrace agriculture Mediterranean", "terrace agriculture interview" and "terrace agriculture" (alone and combined with all the names of countries in the Mediterranean, e.g., terrace agriculture and Spain). In this first phase, all papers selected for review were in English.

We then screened the references of all the papers that we found in order to refine our search until no new papers were found. In this subsequent screening, we selected English-language papers included in the referred scientific literature. We also considered a small number of relevant papers in the Italian language, and it is likely that we have not included a few papers in other languages that might have been relevant. We collated about 500 articles (published up to 2019-2020) that we culled to include only papers ( $\mathrm{N}=285$ ) dealing with terraces (construction, management, vegetation colonization, etc.) within the Mediterranean area. We excluded those papers that only mentioned the presence of terraces in the area but did not analyze them in any way, as well as those papers that discussed the geological features of natural terraces (landforms). We built a database of all the remaining articles $(\mathrm{N}=285)$ (Electronic Supplementary Material, ESM1 Table S1) detailing the type of terrace, the main focus of the paper, the country where the study was performed, and the management practices for the terraces.

\section{Results and Discussion}

There are different types of terraces which differ in shape, structure (e.g., inclination, risers), and construction material (e.g., stones, concrete, earth) [12]. However, they all share a common function of expanding cultivable land [26] with similar outcomes: they modify the landscape, hydrogeology, soil features, and system dynamics $[24,25,27]$. In the Mediterranean area, terraces are a defining feature of the landscape of many regions (Figure 1; ESM1 Table S1) as they are often quite ancient, built with construction techniques that have not changed much over millennia $[25,26,28-30]$. Here, dry stone terraces are the most common, predominantly built on marginal lands, and are now largely abandoned (Figure 2a; ESM1 Tables S2 and S3). The majority of the collated papers (ESM1 Table S3) analyze the changed conditions after abandonment: soil degradation or erosion, vegetation features and dynamics, and historical land-use changes, while only a few explore management operations or strategies for requalification (Figure 2b, Table 1, ESM1 Table S4). Other papers are mostly descriptive (analyzing landscape features or construction techniques) or analyze a variety of environmental conditions for actively cultivated terraces (ESM1 Table S3). Only a handful of papers compare conditions (i.e., soil erosion rates) in different agricultural systems [31-33]. Finally, a minority of the studies involve the participation of farmers, although they are one of the key elements that control the dynamics of the system. 


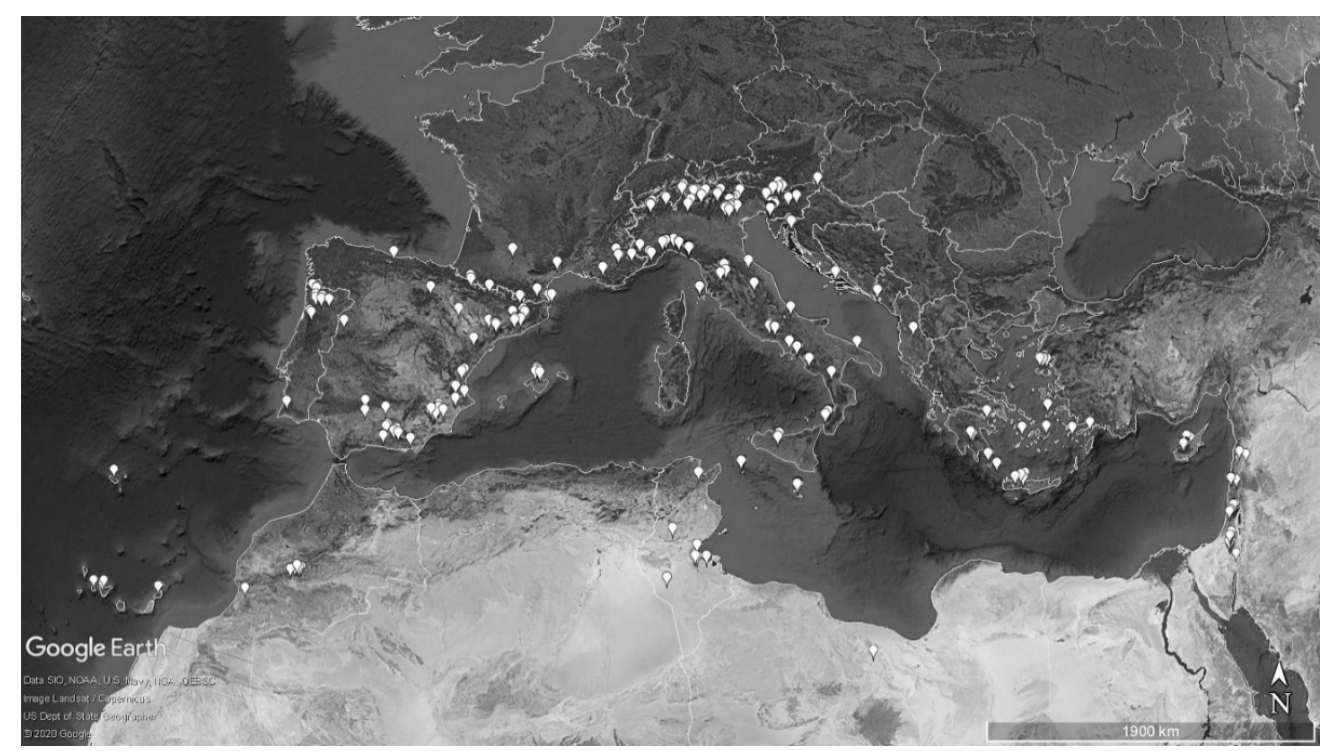

Figure 1. Position of the analyzed case studies around the Mediterranean basin (see also ESM1 Table S1).

$\mathbf{a}$

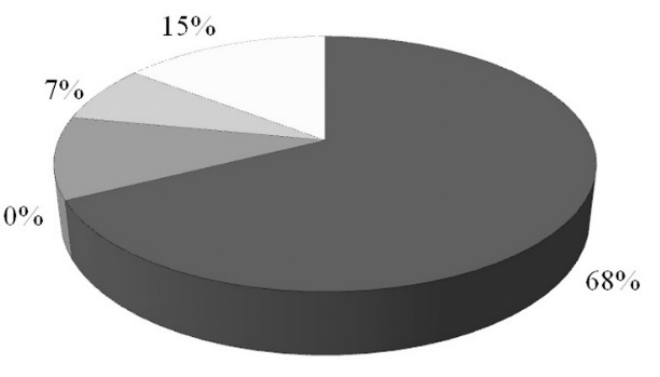

Dry stone walls

$\square$ Earth embankments

$\square$ Mixed: dry stones, earth

embankments.

$\square$ Not available information

b

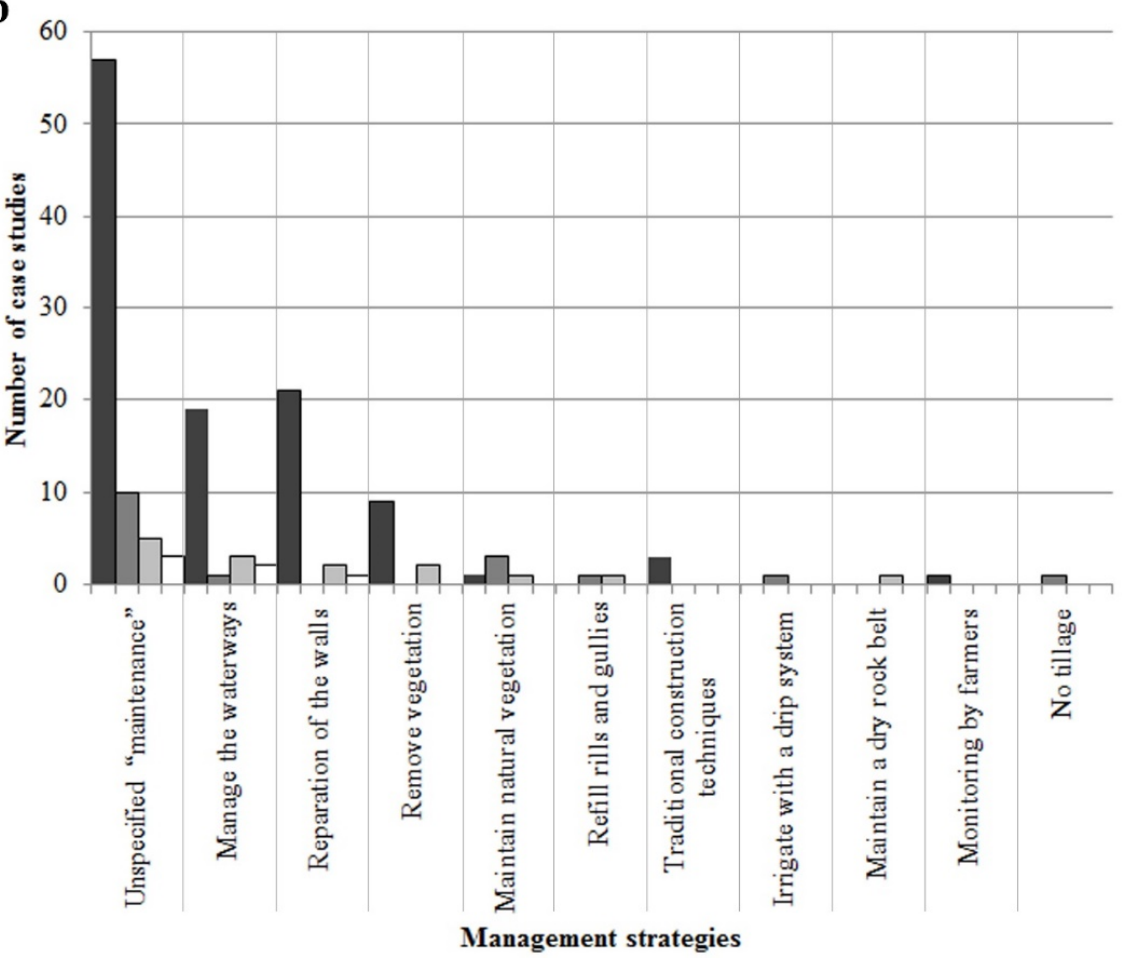

Figure 2. (a) Typology of terraces in the case studies; (b) Management strategies detailed in the analyzed case studies. 
In the analyzed studies, farmers were involved for different reasons and in various ways. Most papers include interviews with farmers to collect information on the management of the farm [34-36] in order to include firsthand data on crops, farm size, etc. Other papers also explore the economic aspect of terrace cultivation with the farmers $[37,38]$. Many studies instead aim to gather the farmers' perspectives on the local terraced landscape [39,40], its history and changes over time [41-43], and on the landscape-tourism interrelationships in terraced landscapes [44,45]. As several collated studies focus on soil erosion, some researchers also include farmers' perceptions on land degradation and the adoption of soil conservation practices [46,47]. On the other hand, not many studies analyze risks, strategies, or management needs with the involvement of farmers [38,43,48,49].

Although it is a shared view in the literature that the maintenance of terraces is essential for a variety of reasons (i.e., erosion control) [25], only a limited number of papers detail management strategies (Figure 2b, ESM1 Table S4). For instance, several papers indicate that dry-stone walls require maintenance without any specifics, although some report that farmers remove vegetation from the walls, keep waterways clear, or repair damaged wall structures [50-52]. Still, these three actions are never mentioned together within the same paper. Only a few papers describe management strategies for broad-base terraces with no built walls (stone or concrete), and they mostly suggest practices (i.e., no tilling and drip irrigation) that can reduce the dislocation of soil (erosion) and thus the destabilization of terraces [53]. Only a limited number of papers explore how plants growing on dry stone walls can affect their structural integrity, although some analyze how plants affect soil erosion on terraces with earth embankments [32,54]. Although many papers recognize the relevance of terraced landscapes and terrace systems, not many discuss what can be done to preserve them, indicating that papers analyze different issues and that implications for management are not well covered in the literature.

Several publications analyze soil features and erosion, or vegetation dynamics, after the abandonment of terraces (ESM1 Table S3). Terraces alter the drainage network of hillslopes and can become prone to erosion, piping, instability, debris flow, and landslides if they are no longer maintained [11]. The evolution of an abandoned terrace depends on its structure (slope, type of wall, bedrock, etc.), but it generally leads to various extents of geomorphic damage, especially when the recolonization of vegetation is disturbed [11,55]. Disturbing events such as fires can halt vegetation dynamics, favoring the establishment of small shrubs or herbaceous communities [56] that are less effective on terrace stability than arboreal vegetation when terraces are already in poor conditions. Often, studies evaluate linkages between the evolution of plant communities and soil stability [57-60], with different perspectives on the vegetation dynamics and terrace collapse [61]. Most of these studies focus on plant development on the flat surfaces of terraces, and only a few examine plant colonization on retaining walls [62,63]. Several researchers analyzed the main factors affecting plant cover and dynamics, investigating their linkages with the time since abandonment $[51,56,57,64,65]$, aspect and edaphic conditions $[60,63,65,66]$, and previous land use $[20,58]$. In several cases, after the abandonment, terraces undergo an increase in vegetation and species diversity $[56,66]$, which can eventually recreate a natural landscape but not the cultural landscape.

The resilience and stability of coupled human-environment systems are often linked to human activities within the system [1,19,67-70]. According to the literature, soil erosion is higher in abandoned terraces, which are also more likely to collapse than those that are managed, with dire consequences for the hydrogeological stability of mountainsides [55,71,72]. Heavy rainfall events, which are becoming more frequent with current climatic changes [73], can also increase the risks of soil erosion and collapse within abandoned terraces $[9,74]$. Furthermore, the restoration of collapsed terraces is more expensive and difficult than periodic maintenance of the walls, which is mostly comprised of a few simple actions (Figure 2b). These actions can thus prevent, or at least reduce, the incidence of landslides and preserve the integrity of the cultural landscape [74]. How to incentivize the farmers to keep maintaining their terraces, however, is a different matter. 
The Mediterranean area hosts many outstanding examples of terraced landscapes, though they are currently changing $[18,25]$. Many people are abandoning agriculture in marginal land, including the cultivation of terraces [24]. Several studies have suggested potential strategies to preserve or restore these landscapes, mostly focusing on economic incentives, community-based initiatives, and tourism [18,75,76] (Table 1). Some researchers instead suggest measures to facilitate the vegetation recolonization of abandoned terraces to reduce the erosion process and failure risks $[53,59,77]$. However, this suggestion does not always consider the value of terraces for the preservation of cultural landscapes. The reconstruction of terraces is often controversial, as restoration does not always adhere to traditional construction techniques [24]. There are several options (Table 1, Figure 3) that can be used to encourage farmers to keep maintaining their terraces, although some options might not be feasible for all regions within the Mediterranean area.

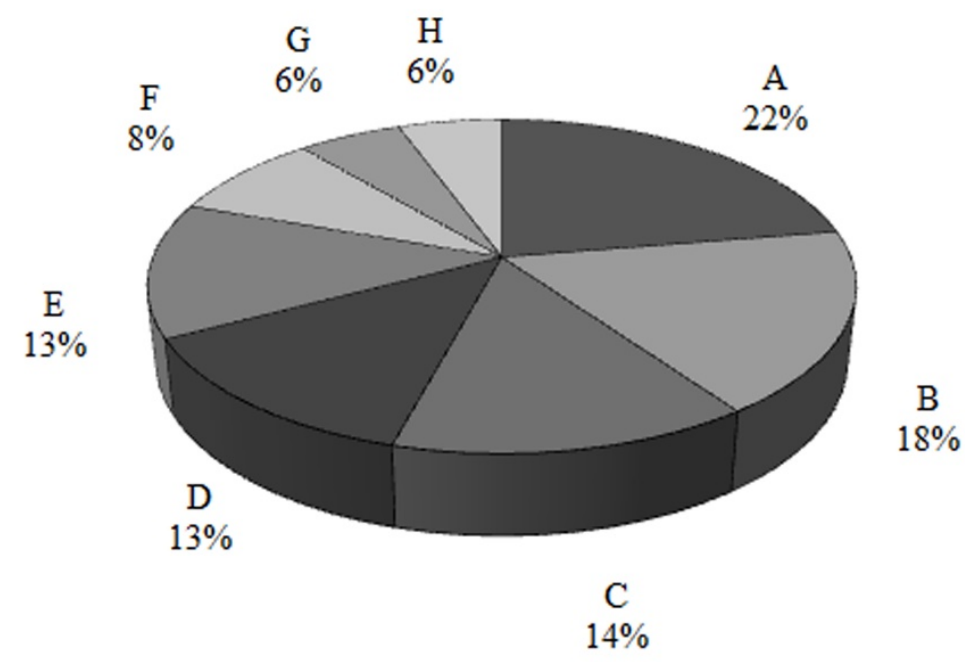

Figure 3. Percentages of the conservation strategies for terraces and terraced landscapes. Legend: (A) Provide financial support. (B) Involve and support local communities. (C) Incentivize the production of high-quality products. (D) Promote touristic initiatives. (E) Recovery/restoration of structures. (F) Mapping and/or monitoring of the terrace system. (G) Implement agricultural infrastructures. $(\mathrm{H})$ Promote re-naturalization.

The literature suggests a variety of options for the conservation or requalification of terraced landscapes. There is a first distinction here, as most studies suggest strategies both for abandoned and cultivated terraces, while other studies suggest that the efforts should be focused on cultivated terraces and renaturalizing abandoned ones [78,79]. In some studies [15,17], researchers recommend the use of financial incentives to rebuild or sustain agriculture on terraces that are generally less lucrative than conventional agriculture. Financial support would easily solve the problem of terrace abandonment, but this option is not easy to implement due to lack of funding at a national level. Other studies suggest the cultivation of new profitable crops [80]. However, the farmers that still cultivate their terraces do so because often they adhere to their local traditions and want to keep cultivating their traditional crops [71]. They will likely need to be encouraged to embrace a multifunctional use of terraces, including the cultivation of new crops [81]. The promotion of touristic activities would be beneficial if specifically tied to terraces and agriculture, because if the tourism sector were to become more lucrative than agriculture, it is likely that people would abandon their farms and terraces. One further option that has been suggested by some researchers [82,83] and has been successfully applied in Italy [84] and outside of the Mediterranean area [85] entails the possibility of renting terraces to hobby farmers and city dwellers.

As terraced systems are coupled human-environment systems, options for the requalification of terraced landscapes should be tailored to the local needs of farmers. Most 
studies simply advocate for the involvement of local communities in planning, and only a few analyze successful community-based conservation projects [86,87]. These two projects involved farmers in all the activities, from the decision-making to the implementation of the selected management actions. As mentioned above, in the Brenta Valley (Italy), terraces were rented to people interested in hobby farming so that they could maintain the terrace structures. Other researchers [78] have described the measures adopted for the restoration/conservation of terraces in a management plan for a terraced area. As an example, the potential use of ethnobotanical plants, which are tied to local traditions, in combination with new crops that can increase farmers' incomes was suggested for the management plan of the Amalfi Coast to foster the preservation of its cultural landscape [81,88]. Finally, two studies $[89,90]$ describe a project involving a local school where students and teachers were involved in restoring a portion of a terraced landscape. Even though there were not many factual examples of local involvement, all of these projects were successful and resulted either in the restoration or in the preservation of a terraced landscape.

Table 1. Conservation strategies for terraces and terraced landscapes and their relative percentages (in the graph at the bottom).

\begin{tabular}{|c|c|c|c|}
\hline $\mathbf{N}$ & Conservation Strategy & Type of Terrace & Country and Reference \\
\hline A & Provide financial support & $\begin{array}{l}\text { Dry stone terraces; earth } \\
\text { embankments; mixed }\end{array}$ & $\begin{array}{c}\text { Spain }[17,91,92] \\
\text { Italy }[15,45,48,49,78,82,87,93-96] \\
\text { Slovenia }[83] \\
\text { Malta }[97-99] \\
\text { Greece }[100,101] \\
\text { Israel }[102] \\
\text { Palestine }[46] \\
\text { Tunisia }[103] \\
\text { Morocco }[104]\end{array}$ \\
\hline $\mathrm{B}$ & $\begin{array}{l}\text { Involve and support } \\
\text { local communities }\end{array}$ & Dry stone terraces; mixed & $\begin{array}{c}\text { Spain }[92] \\
\text { Italy }[45,78,82,84,87,89,90,105-107] \\
\text { Slovenia }[83,108] \\
\text { Malta }[98,99] \\
\text { Cyprus }[86] \\
\text { Greece }[100] \\
\text { Palestine }[46] \\
\text { Morocco }[104]\end{array}$ \\
\hline $\mathrm{C}$ & $\begin{array}{l}\text { Incentivize the production of } \\
\text { high-quality products }\end{array}$ & $\begin{array}{l}\text { Dry stone terraces; earth } \\
\text { embankments; mixed }\end{array}$ & $\begin{array}{c}\text { Spain }[109] \\
\text { Italy }[48,50,71,80,84,87,89,93,94,96,110-112] \\
\text { Cyprus }[86]\end{array}$ \\
\hline $\mathrm{D}$ & Promote touristic initiatives & Dry stone terraces; mixed & $\begin{array}{c}\text { Spain }[44] \\
\text { Italy }[45,48-50,71,82,90,93,94,113] \\
\text { Slovenia }[83] \\
\text { Greece }[45] \\
\text { Palestine [114] }\end{array}$ \\
\hline $\mathrm{E}$ & $\begin{array}{l}\text { Recovery/restoration } \\
\text { of structures }\end{array}$ & Dry stone terraces & $\begin{array}{c}\text { Spain }[115] \\
\text { France }[111] \\
\text { Italy }[45,48,49,78,90,93,94,105,110] \\
\text { Malta [98] } \\
\text { Cyprus [86] } \\
\text { Palestine [46] }\end{array}$ \\
\hline $\mathrm{F}$ & $\begin{array}{l}\text { Mapping and/or monitoring of } \\
\text { the terrace system }\end{array}$ & Dry stone terraces; mixed & $\begin{array}{c}\text { Spain }[91] \\
\text { Italy }[15,48,72,78,94,107] \\
\text { Slovenia }[108] \\
\text { Palestine }[114]\end{array}$ \\
\hline G & $\begin{array}{l}\text { Implement agricultural } \\
\text { infrastructures }\end{array}$ & Dry stone terraces & $\begin{array}{l}\text { Italy }[48,93,110] \\
\text { Cyprus }[79,86] \\
\text { Palestine }[46]\end{array}$ \\
\hline $\mathrm{H}$ & Promote the re-naturalization & Dry stone terraces & $\begin{array}{c}\text { Spain }[64,115] \\
\text { Italy }[48,78] \\
\text { Cyprus }[79,86]\end{array}$ \\
\hline
\end{tabular}




\section{Conclusions}

The periodical management of terraces entails inexpensive and simple, although possibly labor-intensive, actions (i.e., plant removal from terrace walls) that require the active presence of farmers. There is no study, at least in the Mediterranean area, that analyzes how effective these strategies are for the stability of terraces. On the other hand, several studies have demonstrated that the involvement of local farmers and stakeholders is pivotal for the success of conservation/requalification projects. As such, the conservation of terraced landscapes is in the hands of local farmers, and thus they should be actively involved in the decision-making and finding the most suitable strategies for assuring the continuity in farming and preserving cultural landscapes in the Mediterranean area. As terraced landscapes are widespread across the globe, the challenges, management strategies, and conservation options for terraces are diverse, and we advocate for expanding our review to a global level to explore successful strategies for preserving terraced landscapes.

Supplementary Materials: The following are available online at https: / www.mdpi.com/article / 10.3390/su13084475/s1, ESM1. Table S1: List of the collated studies on agricultural terraces in the Mediterranean area. Table S2: Type of terraces (embankments). Table S3: Main focus and other features of the analyzed papers. Table S4: Maintenance strategies for terrace structures.

Author Contributions: E.C. and V.S. performed the literature review; E.C., V.S., and G.C. wrote the manuscript together. All authors have read and agreed to the published version of the manuscript.

Funding: This research received no external funding.

Institutional Review Board Statement: Not applicable.

Informed Consent Statement: Not applicable.

Data Availability Statement: The data presented in this study are available within the paper or in the supplementary material ESM1.

Acknowledgments: The Grant to the Department of Science, Roma Tre University (MIUR-Italy Dipartimenti di Eccellenza, ARTICOLO 1, COMMI 314-337 LEGGE 232/2016) is gratefully acknowledged.

Conflicts of Interest: The authors declare no conflict of interest.

\section{References}

1. Folke, C.; Biggs, R.; Norström, A.V.; Reyers, B.; Rockström, J. Social-ecological resilience and biosphere-based sustainability science. Ecol. Soc. 2016, 21, 3. [CrossRef]

2. Ostrom, E. A General Framework for Analyzing Sustainability of Social-Ecological Systems. Science 2009, 325, 419-422. [CrossRef]

3. Baiamonte, G.; Domina, G.; Raimondo, F.M.; Bazan, G. Agricultural landscapes and biodiversity conservation: A case study in Sicily (Italy). Biodivers. Conserv. 2015, 24, 3201-3216. [CrossRef]

4. Spencer, J.E.; Hale, G.A. The Origin, nature, and Distribution of Agricultural terracing. Pac. Viewp 1961, 2, 1-40. [CrossRef]

5. Doolittle, W.E. Terrace origins: Hypotheses and research strategies. Yearb. Conf. Lat. Am. Geogr. 1990, 16, 94-97.

6. Arnáez, J.; Lana-Renault, N.; Lasanta, T.; Ruiz-Flaño, P.; Castroviejo, J. Effects of farming terraces on hydrological and geomorphological processes: A review. Catena 2015, 128, 122-134. [CrossRef]

7. Chapagain, T.; Raizada, M.N. Agronomic Challenges and Opportunities for Smallholder Terrace Agriculture in Developing Countries. Front. Plant Sci. 2017, 8, 331. [CrossRef] [PubMed]

8. Dorren, L.; Rey, F. A review of the effect of terracing on erosion. In Briefing Papers of the 2nd Scape Workshop; Boix-Fayons, C., Imeson, A., Eds.; SCAPE: Cinque Terre, Italy, 2004; pp. 97-108.

9. Camera, C.; Djuma, H.; Bruggeman, A.; Zoumides, C.; Eliades, M.; Charalambous, K.; Abate, D.; Faka, M. Quantifying the effectiveness of mountain terraces on soil erosion protection with sediment traps and dry-stone wall laser scans. Catena 2018, 171, 251-264. [CrossRef]

10. Kuijt, I.; Finlayson, B.; MacKay, J. Pottery Neolithic landscape modification at Dhra'. Antiquality 2007, 81, 106-118. [CrossRef]

11. Tarolli, P.; Preti, F.; Romano, N. Terraced landscapes: From an old best practice to a potential hazard for soil degradation due to land abandonment. Anthropocene 2014, 6, 10-25. [CrossRef]

12. Wei, W.; Chen, D.; Wang, L.; Daryanto, S.; Chen, L.; Yu, Y.; Lu, Y.; Sun, G.; Feng, T. Global synthesis of the classifications, distributions, benefits and issues of terracing. Earth Sci. Rev. 2016, 159, 388-403. [CrossRef]

13. Treacy, J.M.; Denevan, W.M. The Creation of Cultivable Land through Terracing. In The Archaeology of Garden and Field; Miller, N.F., Gleason, K.L., Eds.; University of Pennsylvania Press: Philadelphia, PA, USA, 1997; pp. 91-110. 
14. Asins Velis, S. structures. In Proceeding of the 1st Conference on Crop Fields and Gardens Archaeology, Barcelona, Spain, 1-3 June 2006; Morel, J.-P., Tresserras, J., Matamala, J.C., Eds.; Edipuglia: Bari, Italy, 2006; pp. 21-40.

15. Agnoletti, M.; Conti, L.; Frezza, L.; Santoro, A. Territorial Analysis of the Agricultural Terraced Landscapes of Tuscany (Italy): Preliminary Results. Sustainatibility 2015, 7, 4564-4581. [CrossRef]

16. Lieskovský, J.; Bezák, P.; Špulerová, J.; Lieskovský, T.; Koleda, P.; Dobrovodská, M.; Bürgi, M.; Gimmi, U. The abandonment of traditional agricultural landscape in Slovakia-Analysis of extent and driving forces. J. Rural Stud. 2015, 37, 75-84. [CrossRef]

17. Asins Velis, S.; Arnau-Rosalen, E.; Romero-Gonzalez, J.; Calvo-Cases, A. Analysis of the consequences of the european union criteria on slope gradient for the delimitation of "areas facing natural constraints" with agricultural terraces. Ann. Anal. Istrske Mediter. Studije Ser. Hist. Sociol. 2016, 26, 433-448.

18. Varotto, M.; Ferrarese, F.; Pappalardo, S.E. Italian Terraced Landscapes: The Shapes and the Trends. In World Terraced Landscapes: History, Environment, Quality of Life; Varotto, M., Bonardi, L., Tarolli, P., Eds.; Springer: Cham, Switzerland, 2018 ; pp. $27-43$.

19. Benayas, J.M.R.; Martins, A.; Nicolau, J.M.; Schulz, J.J. Abandonment of agricultural land: An overview of drivers and consequences. CAB Rev. 2007, 2, 1-14. [CrossRef]

20. Cyffka, B.; Bock, M. Degradation of field terraces in the Maltese Islands-reasons, processes and effects. Din. Quat. 2008, 31, 119-128.

21. Bonardi, L. Terraced Vineyards in Europe: The Historical Persistence of Highly Specialised Regions. In World Terraced Landscapes: History, Environment, Quality of Life Environmental History; Varotto, M., Bonardi, L., Tarolli, P., Eds.; Springer: Cham, Switzerland, 2019; pp. 7-29.

22. Tillmann, H.J.; Salas, M.A. The mountain / coastal sea farmers and the stone walls of the terraces resist the threats to terraced landscapes and cultures: ITLA the International Terraced Landscapes Alliance. Ann. Anal. Istrske Mediter. Studije Ser. Hist. Sociol. 2016, 26, 375-388.

23. Walker, B.; Carpenter, S.; Anderies, J.; Abel, N.; Cumming, G.; Janssen, M.; Lebel, L.; Norberg, J.; Peterson, G.D.; Pritchard, R. Resilience management in social-ecological systems: A working hypothesis for a participatory approach. Conserv. Ecol. 2002, 6, 1. [CrossRef]

24. Stanchi, S.; Freppaz, M.; Agnelli, A.; Reinsch, T.; Zanini, E. Properties, best management practices and conservation of terraced soils in Southern Europe (from Mediterranean areas to the Alps): A review. Quat. Int. 2012, 265, 90-100. [CrossRef]

25. Moreno-de-las-Heras, M.; Lindenberger, F.; Latron, J.; Lana-Renault, N.; Llorens, P.; Arnáez, J.; Romero-Díaz, A.; Gallart, F. Hydro-geomorphological consequences of the abandonment of agricultural terraces in the Mediterranean region: Key controlling factors and landscape stability patterns. Geomorphology 2019, 333, 73-91. [CrossRef]

26. Bevan, A.; Conolly, J. Terraced fields and Mediterranean landscape structure: An analytical case study from Antikythera, Greece. Ecol. Model. 2011, 222, 1303-1314. [CrossRef]

27. Nunes, J.P.; Bernard-Jannin, L.; Rodriguez Blanco, M.L.; Santos, J.M.; Coelho, C.D.; Keizer, J.J. Hydrological and erosion processes in terraced fields: Observations from a humid Mediterranean region in Northern Portugal. Land Degrad Dev. 2018, 29 , 596-606. [CrossRef]

28. Ron, Z. Agricultural terraces in the Judean Mountains. Isr. Explor. J. 1966, 16, 33-49.

29. Fall, P.L.; Falconer, S.E.; Galletti, C.S.; Shirmang, T.; Ridder, E.; Klinge, J. Long-term agrarian landscapes in the Troodos foothills, Cyprus. J. Archaeol. Sci. 2012, 39, 2335-2347. [CrossRef]

30. Ore, G.; Bruins, H.J. Design features of ancient agricultural terrace walls in the Negev desert: Human-made geodiversity. Land Degrad. Dev. 2012, 23, 409-418. [CrossRef]

31. Al Ali, Y.; Touma, J.; Zante, P.; Nasri, S.; Albergel, J. Water and sediment balances of a contour bench terracing system in a semi-arid cultivated zone (El Gouazine, central Tunisia). Hydrolog. Sci. J. 2008, 53, 883-892. [CrossRef]

32. Duran Zuazo, V.H.; Pleguezuelo, C.R.; Peinado, F.M.; De Graaff, J.; Martínez, J.F.; Flanagan, D.C. Environmental impact of introducing plant covers in the taluses of terraces: Implications for mitigating agricultural soil erosion and runoff. Catena 2011, 84, 79-88. [CrossRef]

33. Ackermann, O.; Zhevelev, H.M.; Svoray, T. Agricultural systems and terrace pattern distribution and preservation along climatic gradient: From sub-humid Mediterranean to arid conditions. Quat. Int. 2019, 502, 319-326. [CrossRef]

34. Segui, J.R. Traditional Pastoralism in the Fageca and Famorca Villages (Mediterranean Spain): An Ethnoarchaeological Approach. Ph.D. Thesis, University of Leicester, Leicester, UK, 1999.

35. Masri, Z.; Zobisch, M. Stone wall bench terraces (Syria). In Where the Land is Greener: Case Studies and Analysis of Soil and Water Conservation Initiatives Worldwide; Liniger, H., Critchley, W., Gurtner, M., Schwilch, G., Mekdaschi Studer, R., Eds.; WOCAT: Bern, Germany, 2007; pp. 249-252.

36. Otero, I.; Boada, M.; Tàbara, J.D. Social-ecological heritage and the conservation of Mediterranean landscapes under global change. A case study in Olzinelles (Catalonia). Land Use Pol. 2013, 30, 25-37. [CrossRef]

37. Giourga, C.; Loumou, A.; Tsevreni, I.; Vergou, A. Assessing the sustainability factors of traditional olive groves on Lesvos Island, Greece. Geo J. 2008, 73, 149-159.

38. Kizos, T.; Koulouri, M.; Vakoufaris, H.; Psarrou, M. Preserving Characteristics of the Agricultural Landscape through AgriEnvironmental Policies: The Case of Cultivation Terraces in Greece. Landsc. Res. 2010, 35, 577-593. [CrossRef] 
39. Sayadi, S. Non-trade amenities for sustainable management of Mediterranean Rural Areas: The environmental goods of traditional mountainous agrarian systems in the South-eastern of Spain. In Agroforestry Systems as a Technique for Sustainable Land Management; Mosquera-Losada, M.R., Fernández-Lorenzo, J.L., Rigueiro-Rodríguez, A., Eds.; AECID: Madrid, Spain, 2009; pp. 131-144. Available online: https:/ / euraf.isa.utl.pt/sites/default/files/pub/docs/af_aecid_en.pdf (accessed on 23 November 2020).

40. De Pasquale, G. Terraced landscapes in southern Italy: Comparative analysis between the past, present and future. Ann. Anal. Istrske Mediter. Studije Ser. Hist. Sociol. 2018, 28, 709-724.

41. Bevan, A.; Conolly, J.; College, S.; Frederick, C.; Palmer, C.; Siddall, R.; Stellatou, A. The long-term ecology of agricultural terraces and enclosed fields from Antikythera, Greece. Human Ecol. 2013, 41, 255-272. [CrossRef]

42. Kizos, T.; Koulouri, M. Agricultural landscape dynamics in the Mediterranean: Lesvos (Greece) case study using evidence from the last three centuries. Environ. Sci. Policy 2006, 9, 330-342. [CrossRef]

43. Kizos, T.; Dalaka, A.; Petanidou, T. Farmers' attitudes and landscape change: Evidence from the abandonment of terraced cultivations on Lesvos, Greece. Agr. Hum. Values 2010, 27, 199-212. [CrossRef]

44. Pereira Dra, D.; Recio, S.; Carlos Gonzalo, J. Evolution of the landscape as a response of a demographic change. A case study in the Duero riverside, Spain. Local Environ. 2010, 15, 419-431. [CrossRef]

45. Terkenli, T.S.; Cisani, M.; Castiglioni, B. Is there a future for tourism in terraced landscapes? A comparative study of landscape resources and tourism consequences in Valtellina (Italy) and Lesvos (Greece). Ann. Anal. Istrske Mediter. Studije Ser. Hist. Sociol. 2018, 28, 725-740.

46. Hammad, A.A.; Børresen, T. Socioeconomic factors affecting farmers' perceptions of land degradation and stonewall terraces in central Palestine. Environ. Manag. 2006, 37, 380-394. [CrossRef]

47. Estabrook, G.F. Living Grass Irrigation Ditches in Traditional Portuguese Agriculture: Autecology in the study of ethnobotany. Ethnobot. Res. Appl. 2007, 5, 319-330. [CrossRef]

48. Contessa, V. Terraced Landscapes in Italy: State of the Art and Future Challenges. Master's Thesis, Università degli Studi di Padova, Padua, Italy, 2014.

49. Nicolosi, A.; Cambareri, D.; Petulla, M. A socioeconomic survey for the recovery and exploitation of the terraced vineyards of the Costa Viola (Calabria, Italy). In Proceedings of the European Association of Agricultural Economists (EAAE) International Congress, EAAE, Copenhagen, Denmark, 23-27 August 2005.

50. Di Fazio, S. I terrazzamenti viticoli della Costa Viola Caratteri distintivi del paesaggio, trasformazioni in atto e gestione territoriale in un caso-studio in Calabria [terraced vineyards of Costa Viola: Characteristics of the landscape, ongoing transformations and management in a case study in the Calabria region]. I Georgofili Quaderni 2008, 2, 69-92.

51. Palmer, C.; Colledge, S.; Bevan, A.; Conolly, J. Vegetation recolonisation of abandoned agricultural terraces on Antikythera, Greece. Environ. Archaeol. 2010, 15, 64-80. [CrossRef]

52. Momirski, L.A.; Gabrovec, M. Changes in land use in the Mediterranean terraced landscapes between 1819 and 2012 : The case of two selected villages in Slovenia. In Land Use, Cover Changes in Selected Regions in the World; Himiyama, Y., Mather, A., Bicik, I., Milanova, E.V., Eds.; IGU-LUCC: Hokaido, Japan, 2014; pp. 33-42.

53. Duran Zuazo, V.H.; Aguilar Ruiz, J.; Martinez Raya, A.; Franco Tarifa, D. Impact of erosion in the taluses of subtropical orchard terraces. Agric. Ecosyst. Environ. 2005, 107, 199-210. [CrossRef]

54. Duran Zuazo, V.H.; Martínez Raya, A.; Aguilar Ruiz, J. Nutrient losses by runoff and sediment from the taluses of orchard terraces. Water Air Soil Pollut. 2004, 153, 355-373. [CrossRef]

55. García-Ruiz. J.M.; Lana-Renault, N. Hydrological and erosive consequences of farmland abandonment in Europe, with special reference to the Mediterranean region-A review. Agric. Ecosyst. Environ. 2011, 140, 317-338. [CrossRef]

56. Koulouri, M.; Giourga, C. Land abandonment and slope gradient as key factors of soil erosion in Mediterranean terraced lands. Catena 2007, 69, 274-281. [CrossRef]

57. Ruecker, G.; Schad, P.; Alcubilla, M.M.; Ferrer, C. Natural regeneration of degraded soils and site changes on abandoned agricultural terraces in Mediterranean Spain. Land Degrad. Dev. 1998, 19, 488-501. [CrossRef]

58. Ginés, Á. Agriculture, grazing and land changes at the Serra de Tramuntana karstic mountains. Int. J. Speleol. 1999, 28, 1. [CrossRef]

59. Arbelo, C.D.; Rodríguez-Rodríguez, A.; Guerra, J.A.; Mora, J.L.; Notario, J.S.; Fuentes, F. Soil degradation processes and plant colonization in abandoned terrace fields overlying pumice tuffs. Land Degrad. Dev. 2006, 17, 571-588. [CrossRef]

60. Cyffka, B. Experiences in the study of land cover transformation on Mediterranean islands caused by change in land tenure. In Environmental Security and Sustainable Land Use-with Special Reference to Central Asia; Vogtmann, H., Dobretsov, N., Eds.; Springer: Dordrecht, The Netherlands, 2006; pp. 85-103.

61. Faulkner, H.; Ruiz, J.; Zukowskyj, P.; Downward, S. Erosion risk associated with rapid and extensive agricultural clearances on dispersive materials in southeast Spain. Environ. Sci. Policy 2003, 6, 115-127. [CrossRef]

62. Filesi, L. Col delle ventidue ore: The vegetal landscape in the terraced fields of the Canale di Brenta. In Terraced Landscapes of the Alps Projects in Progress; Fontanari, E., Patassini, D., Eds.; Marsilio: Venice, Italy, 2008; pp. 51-54.

63. Barbera, G.; Cullotta, S.; Rossi-Doria, I.; Rühl, J.; Rossi-Doria, B. I Paesaggi a Terrazze in Sicilia: Metodologie per L'analisi, la Tutela e la Valorizzazione; ARPA: Sicilia, Palermo, Italy, 2010. 
64. Bonet, A. Secondary succession of semi-arid Mediterranean old fields in south-eastern Spain: Insights for conservation and restoration of degraded lands. J. Arid. Environ. 2004, 56, 213-233. [CrossRef]

65. Rühl, J.; Pasta, S.; Schnittler, M. A chronosequence study of vegetation dynamics on abandoned vine and caper terraces of Pantelleria Island (Sicily). Arch. Nat. Conserv. Landsc. Res. 2006, 45, 71-94.

66. Blasi, C.; Di Pietro, R.; Fortini, P. A phytosociological analysis of abandoned terraced olive grove shrublands in the Tyrrhenian district of Central Italy. Plant Biosyst. 2000, 134, 305-331. [CrossRef]

67. Berkes, F.; Colding, J.; Folke, C. Rediscovery of Traditional Ecological Knowledge as adaptive management. Ecol. Appl. 2000, 10, 1251-1262. [CrossRef]

68. Liu, J.; Dietz, T.; Carpenter, S.R.; Alberti, M.; Folke, C.; Moran, E.; Pell, A.N.; Deadman, P.; Kratz, T.; Lubchenco, J.; et al. Complexity of coupled human and natural systems. Science 2007, 317, 1513-1516. [CrossRef] [PubMed]

69. Folke, C.; Carpenter, S.R.; Walker, B.; Scheffer, M.; Chapin, T.; Rockström, J. Resilience thinking: Integrating resilience, adaptability and transformability. Ecol. Soc. 2010, 15, 4. [CrossRef]

70. Rounsevell, M.D.A.; Robinson, D.T.; Murray-Rust, D. From actors to agents in socio-ecological systems models. Philos. Trans. R. Soc. B 2012, 367, 259-269. [CrossRef]

71. Savo, V.; Caneva, G.; McClatchey, W.; Reedy, D.; Salvati, L. Combining environmental factors and agriculturalists' observations of environmental changes in the traditional terrace system of the Amalfi Coast (Southern Italy). Ambio 2014, 43, 297-310. [CrossRef]

72. Capolupo, A.; Kooistra, L.; Boccia, L. A novel approach for detecting agricultural terraced landscapes from historical and contemporaneous photogrammetric aerial photos. Int. J. Appl. Earth Obs. Geoinf. 2018, 73, 800-810. [CrossRef]

73. Fischer, E.M.; Knutti, R. Observed heavy precipitation increase confirms theory and early models. Nat. Clim. Chang. 2016, 6, 986-991. [CrossRef]

74. Agnoletti, M.; Errico, A.; Santoro, A.; Dani, A.; Preti, F. Terraced Landscapes and Hydrogeological Risk Effects of Land Abandonment in Cinque Terre (Italy) during Severe Rainfall Events. Sustainability 2019, 11, 235. [CrossRef]

75. Varras, G.; Kantartzis, A.; Kakouri, P.; Koutsikou, M.; Papadopoulou, A. Use of Terraces in the Mediterranean Environment: A physical, sociohistorical, and economic approach. The case of Greece. In Proceedings of the 2006 Naxos International Conference on Sustainable Management and Development of Mountainous and Island Areas, Island of Naxos, Greece, 26 September-1 October 2006; Manolas, E.I., Ed.; University of Crete: Heraklion, Greece, 2006; pp. 330-342.

76. Fontanari, E.; Patassini, D. Planning, Policies and Governance for Terraced Landscape: A General View. In World Terraced Landscapes: History, Environment, Quality of Life; Varotto, M., Bonardi, L., Tarolli, P., Eds.; Springer: Cham, Switzerland, 2019; pp. 323-333.

77. Lesschen, J.P.; Cammeraat, L.H.; Nieman, T. Erosion and terrace failure due to agricultural land abandonment in a semi-arid environment. Earth Surf. Proc. Land 2008, 33, 1574-1584. [CrossRef]

78. Benetti, G.; Patassini, D. Principles and Laws of Protection, Conservation and Restoration for the Terracing of the Canale di Brenta. In Terraced Landscapes of the Alps. Projects in Progress; Fontanari, E., Patassini, D., Eds.; Marsilio: Venice, Italy, 2008 ; pp. 104-108.

79. Zoumides, C.; Bruggeman, A.; Djuma, H.; Camera, C.; Giannakis, E. Soil Threats and Ecosystems Services in the Trood Mountains of Cyprus. Geophys. Res. Abstr. 2015, 17, 14937-14941.

80. ARPAV. I Suoli dei Versanti Terrazzati di Valstagna [Soils of the Terraced Mountainsides in Valstagna] (Mori-Mattietti, Valverta e Col Ventidueore); ARPAV: Veneto, Italy, 2006.

81. Caneva, G.; Cancellieri, L.; Tufano, M.; Savo, V. Indicazioni gestionali su Agricoltura, Etnobotanica e Aree di interesse naturalistico (con considerazioni sui possibili effetti del cambiamento climatico. In Il futuro dei Territori antichi. Problemi, Prospettive e Questioni di Governance dei Paesaggi Culturali Evolutivi Viventi; Ferrigni, F., Sorrentino, M.C., Eds.; EdiPuglia: Bari, Italy, 2013 ; pp. 167-178.

82. Paliaga, G.; Giostrella, P.; Faccini, F. Terraced landscape as cultural and environmental heritage at risk: An example from Portofino Park (Italy). Ann. Anal. Istrske Mediter. Studije Ser. Hist. Sociol. 2016, 26, 513-522.

83. Šmid Hribar, M.; Geršič, M.; Pipan, P.; Repolusk, P.; Tiran, J.; Topole, M. Cultivated terraces in Slovenian landscapes. Acta Geogr. Slov. 2017, 57, 83-97. [CrossRef]

84. Stempfle, S. Innovating lands access conditions to rescue a threatened heritage: The project Adopt a terrace in the Brenta Valley In Proceedings of the Second International Conference on Agriculture in an Urbanizing Society Reconnecting Agriculture and Food Chains to Societal Needs, Rome, Italy, 14-17 September 2015; pp. 473-474.

85. Qiu, Z.; Chen, B.; Takemoto, K. Conservation of terraced paddy fields engaged with multiple stakeholders: The case of the Noto GIAHS site in Japan. Paddy Water Environ. 2014, 12, 275-283. [CrossRef]

86. Zoumides, C.; Bruggeman, A.; Giannakis, E.; Camera, C.; Djuma, H.; Eliades, M. Community-based rehabilitation of mountain terraces in Cyprus. Land Degrad. Dev. 2017, 28, 95-105. [CrossRef]

87. Torquati, B.; Cecchini, L.; Venanzi, S.; Giacchè, G. Economic Analysis of the Traditional Cultural Terraced Olive-growing Landscape and Participatory Planning Process. In World Terraced Landscapes: History, Environment, Quality of Life; Varotto, M., Bonardi, L., Tarolli, P., Eds.; Springer: Cham, Switzerland, 2019; pp. 251-271.

88. Savo, V. Usi Delle Piante in Costiera Amalfitana-Uses of Plants in the Amalfi Coast; Officine Zefiro: Amalfi, Italy, 2010.

89. Cevasco, A.; Rollando, A. Bringing a historical citrus grove back to life. In Terraced Landscapes of the Alps. Projects in Progress; Fontanari, E., Patassini, D., Eds.; Marsilio: Venice, Italy, 2008; pp. 57-59. 
90. Werder, S.; Andrei, F.; Beti, M.; Michael, M. Revitalizing a historical chestnut wood. In Terraced Landscapes of the Alps. Projects in Progress; Fontanari, E., Patassini, D., Eds.; Marsilio: Venice, Italy, 2008; pp. 60-62.

91. Gimenez-Font, P. The landscape of agricultural terraces in mountainous areas in the region of Valencia (eastern Spain). The construction and decline of a cultural heritage. In Produits Agricoles, Touristiques et Développment Local; Kerzazi, M., Hamza, M.A., El Assad, M., Eds.; Association Nationale des Géographes Marocains (ANAGEM), Groupe de Recherche sur le Monde Rural (GREMR), Union Géographique Internationale, Commission sur le Développement Durable \& les Systèmes Ruraux: Casablanca, Morocco, 2011; pp. 307-317.

92. Lasanta, T.; Arnaéz, J.; Ruiz Flaño, P.; Lana-Renault, N. Agricultural terraces in the Spanish mountains: An abandoned landscape and a potential resource. Boletín Asoc. Geógrafos Españoles 2013, 63, 487-491.

93. Benetti, G.; Chemin, A.; Fontanari, E.; Patassini, D. The Parco del Sole: A project for the areas of Mattietti and Casarette. In Terraced Landscapes of the Alps. Projects in Progress; Fontanari, E., Patassini, D., Eds.; Marsilio: Venice, Italy, 2008 ; pp. 77-99.

94. Di Fazio, S.; Modica, G. Le Pietre Sono Parole: Letture del Paesaggio dei Terrazzamenti Agrari della Costa Viola; Iiriti Editore: Reggio Calabria, Italy, 2008.

95. Agnoletti, M.; Cargnello, G.; Gardin, L.; Santoro, A.; Bazzoffi, P.; Sansone, L.; Pezza, L.; Belfiore, N. Traditional landscape and rural development: Comparative study in three terraced areas in northern, central and southern Italy to evaluate the efficacy of GAEC standards 4.4 of cross compliance. Ital. J. Agron. 2011, 6, 121-139. [CrossRef]

96. Modica, G.; Praticò, S.; Di Fazio, S. Abandonment of traditional terraced landscape: A change detection approach (a case study in Costa Viola, Calabria, Italy). Land Degrad. Dev. 2017, 28, 2608-2622. [CrossRef]

97. Rolè, A.; Attard, G. The cost of soil replacement: A Maltese case study. In Determining an Income-Product Generating Approach for Soil Conservation Management, Conference proceedings, Marrakech, Morocco, 12-16 February 2004; MEDCOASTLAND publication 2; IAM: Bari, Italy, 2004.

98. Rolè, A.; Muscat, J.; Camilleri, S.; Camilleri, P.; Scicluna, K.; Sammut Sonya, J.; Attard, G. Sustainable rural land management in the Maltese Islands: An evaluation of policy instruments and future needs. In Drafting Appropriate Policies and Guidelines to Support Sustainable land Management in the Mediterranean Region, Workshop Proceedings, Bari, Italy, 6-11 September 2005; MEDCOASTLAND publication 4; IAM: Bari, Italy, 2005.

99. Rolè, A. The Terraced landscapes of the Maltese Islands. In Europe's Living Landscapes; Pedroli, B., van Doorn, A., de Blust, G., Eds.; KNNV Publishing: Utrecht, The Netherlands, 2007; pp. 405-420.

100. Petropoulou, E.A. Indigenous resource management and environmental degradation: Southern Greece. Manag. Environ. Qual. 2007, 18, 152-166. [CrossRef]

101. Kizos, T.; Koulouri, M. Same land cover, same land use at the large scale, different landscapes at the small scale: Landscape change in olive plantations on Lesvos Island, Greece. Landsc. Res. 2010, 35, 449-467. [CrossRef]

102. Stavi, I.; Rozenberg, T.; Al-Ashhab, A.; Argaman, E.; Groner, E. Failure and collapse of ancient agricultural stone terraces: On-site effects on soil and vegetation. Water 2018, 10, 1400. [CrossRef]

103. Missaoui, H. Soil and water conservation in Tunisia. In Sustainability of Irrigated Agriculture; Pereira, L.S., Feddes, R.A., Gilley, J.R., Lesaffre, B., Eds.; Springer: Berlin, Germany, 1996; pp. 121-135.

104. Ziyadi, M.; Dahbi, A.; Aitlhaj, A.; El Ouahrani, A.; El Ouahidi, A.; Achtak, H. Terraced Agroforestry Systems in West Anti-Atlas (Morocco): Incidence of Climate Change and Prospects for Sustainable Development. In Climate Change-Resilient Agriculture and Agroforestry; Castro, P., Azul, A., Leal Filho, W., Azeiteiro, U., Eds.; Springer: Cham, Switzerland, 2019; pp. 1-19.

105. Chemin, A.; Varotto, M. Veneto. The "masiere" of the Brenta Valley. In Terraced Landscapes of the Alps; Scaramellini, G., Varotto, M., Eds.; Marsilio: Venice, Italy, 2008; pp. 97-101.

106. Lasen, C.; Fagarazzi, L. Terraced systems in the Alpine Region: Plant biodiversity and nature value. In Terraced Landscapes of the Alps; Scaramellini, G., Varotto, M., Eds.; Marsilio: Venice, Italy, 2008; pp. 55-60.

107. Preti, F.; Errico, A.; Caruso, M.; Dani, A.; Guastini, E. Dry-stone wall terrace monitoring and modelling. Land Degrad. Dev. 2018, 29, 806-1818. [CrossRef]

108. Momirski, L.A.; Berčič, T. Ignored regions: Slovenian terraced landscapes. Ann. Anal. Istrske Mediter. Studije Ser. Hist. Sociol. 2016, 26, 399-418.

109. Pleguezuelo, C.R.; Duran Zuazo, V.; Fernandez, J.M.; Peinado, F.M.; Tarifa, D.F. Litter decomposition and nitrogen release in a sloping Mediterranean subtropical agroecosystem on the coast of Granada (SE, Spain): Effects of floristic and topographic alteration on the slope. Agric. Ecosyst. Environ. 2009, 134, 79-88. [CrossRef]

110. Terranova, R. Il paesaggio costiero terrazzato delle Cinque Terre in Liguria. Studi Ric. Geogr. 1989, 12, 1-58.

111. Castex, J.-M.; Dagorne, A.; Gorda, F. Donkeys and terracing in the Valle dell'Estéron. In Terraced Landscapes of the Alps. Projects in Progress; Fontanari, E., Patassini, D., Eds.; Marsilio: Venice, Italy, 2008; pp. 55-56.

112. Freppaz, M.; Agnelli, A.; Drusi, B.; Stanchi, S.; Galliani, C.; Revel Chion, V.; Zanini, E. Valle d'Aosta. Terraced "pergola" vineyards in the low Aosta Valley. In Terraced Landscapes of the Alps; Scaramellini, G., Varotto, M., Eds.; Marsilio: Venice, Italy, 2008 ; pp. 84-87.

113. Di Fazio, S.; Malaspina, D.; Modica, G. La gestione territoriale dei paesaggi agrari terrazzati tra conservazione e sviluppo. In Proceedings of the National Congress of AIIA (Italian Society of Agricultural Engineers) Ingegneria Agraria per lo Sviluppo Sostenibile in Area Mediterranea, Catania, Italy, 27-30 June 2005. 
114. Ghadban, S. Palestinian dry-stone structures: An endogenous expression of cultural landscape. Sustaibable Dev. Cult. Tradit. 2015, $1 b, 34-47$.

115. Arévalo, J.R.; Fernández-Lugo, S.; Reyes-Betancort, J.A.; Tejedor, M.; Jiménez, C.; Díaz, F.J. Relationships between soil parameters and vegetation in abandoned terrace fields vs. non-terraced fields in arid lands (Lanzarote, Spain): An opportunity for restoration. Acta Oecol. 2017, 85, 77-84. [CrossRef] 